Jurnal

\title{
Atrial Electromehanical Interval Using Tissue Doppler as Predictor of Atrial Fibrillation After Coronary Artery Bypass Grafting
}

\author{
Ignatius Yansen, Amiliana Mardiani, Poppy S Roebiono
}

Department of Cardiology and Vascular Medicine, Faculty of Medicine, University of Indonesia and National Cardiovascular Center Harapan Kita, Jakarta

\begin{abstract}
Background. Atrial fibrillation (AF) is the most common arrhythmia complication in patient undergone coronary artery bypass grafting (CABG) with the incidence of $20-50 \%$ according to different studies. Although this complication is temporary but can be life threathening, and increased the number of mortality and morbidity. Thus, it is very important to identified factors that can predict the occurance of AF post CABG. This study use atrial electromechanical interval and interval dispertion as predictor of AF post CABG.

Methods. One hundred and eight patients were included in this case control study. Samples were taken consecutively from May to September 2012 among patients with coronary artery disease undergoing CABG at the National Cardiovascular Center Harapan Kita Jakarta. The patients underwent a preoperative transthoracic echocardiography with tissue doppler evaluation. We measured the atrial electromechanical interval in the lateral of left atrium, septal and lateral of right atrium also inter and intra atrial interval dispertion. Patients was monitored thorugh out hospitalization for the occurance of AF.

Result. In our study, 27 out of 108 (25\%) patients developed AF post CABG. There are 3 independent parameters that can predict AF post CABG. These parameters are electromechanical interval in lateral left atrium, left atrial volume index, and post operative beta blocker. There are longer electromechanical interval in lateral left atrium in patients with $\mathrm{AF}$ post CABG $(8 \mathrm{I}, 12 \pm 9,84 \mathrm{~ms}$ vs $64,43 \pm 13,53 \mathrm{~ms}, P=0.00)$. Patients with $A F$ had bigger left atrial volume index $\left(37,3 \mathrm{I} \pm 9,50 \mathrm{ml} / \mathrm{m}^{2}\right.$ vs $30,28 \pm 8,19 \mathrm{ml} / \mathrm{m}^{2}$, $\mathrm{P}=0.037)$ and more beta blocker post CABG $(20(74,1 \%)$ vs $72(88,9 \%)$, $P=0.026)$. There are no difference intra and interatrium dispertion of electromechanical interval.

Conclusion. The interval of Electromechanical in the lateral left atrium using tissue dopper echocardiography can predict the occurrence of $\mathrm{AF}$ post CABG.
\end{abstract}

(J Kardiol Indones. 2013;34:8I-9I)

Keywords: Atrial Fibrillation, post coronary artery bypass grafting, electromechanical interval, tissue doppler, dispertion of electromechanical interval 
Jurnal

Kardiologi Indonesia

J Kardiol Indones. 2013;34:8I-91

ISSN 0I26/3773

\title{
Interval Elektromekanikal Atrium Menggunakan Doppler Jaringan Sebagai Prediktor Kejadian Fibrilasi Atrium Pasca Operasi Bedah Pintas Arteri Koroner
}

\author{
Ignatius Yansen, Amiliana Mardiani, Poppy S Roebiono
}

\begin{abstract}
Latar Belakang. Fibrilasi atrium (AF) adalah komplikasi aritmia yang paling sering ditemukan pada pasien yang menjalani operasi bedah pintas arteri koroner (BPAK). Insidensinya dilaporkan sangat bervariasi antara 20-50\%. Walaupun diketahui sebagai gangguan yang bersifat sementara namun AF pasca operasi dapat mengancam jiwa serta dikaitkan juga dengan peningkatan angka kesakitan dan kematian yang bermakna. Sehingga diperlukan identifikasi terhadap faktor-faktor yang dapat menjadi prediktor terhadap kejadian AF pasca BPAK. Penelitian ini menilai interval elektromekanikal atrium menggunakan doppler jaringan dan dispersi interval elektromekanikal sebagai prediktor kejadian AF pasca BPAK.

Metode. Seratus delapan pasien diambil secara konsekutif untuk studi case control ini, mulai bulan Mei hingga September 2012 dari antara pasien penyakit jantung koroner yang menjalani operasi BPAK di Pusat Jantung Nasional Harapan Kita, Jakarta. Pasien-pasien ini menjalani pemeriksaan echokardiografi sebelum menjalani operasi BPAK. Dilakukan penilaian terhadap interval elektromekanikal dengan doppler jaringan pada lateral atrium kiri, septal dan lateral atrium kanan serta dispersi interval baik intra maupun interatrial. Pasien dimonitor selama perawatan terhadap kejadian AF.

Hasil. Dalam studi kami, 27 dari 108 (25\%) pasien mengalami AF pasca operasi BPAK. Setelah dilakukan analisis terdapat 3 parameter yang menjadi prediktor independen terhadap kejadian AF pasca BPAK yaitu interval elektromekanikal di lateral atrium kiri, indeks volume atrium kiri dan pemberian obat penyekat reseptor beta setelah operasi BPAK. Didapatkan perbedaan interval elektromekanikal di lateral atrial kiri yang bermakna pada pasien dengan AF pasca BPAK dibandingkan dengan pasien yang tidak mengalami $\mathrm{AF}(81,12 \pm 9,84 \mathrm{~ms}$ vs $64,43 \pm 13,53 \mathrm{~ms}, \mathrm{P}=0.00)$. Pasien dengan AF mempunyai indeks volume atrium kiri yang lebih besar $\left(37,31 \pm 9,50 \mathrm{ml} / \mathrm{m}^{2}\right.$ vs $\left.30,28 \pm 8,19 \mathrm{ml} / \mathrm{m}^{2}, \mathrm{P}=0.037\right)$ dan lebih banyak diberikan obat penyekat reseptor beta $(20(74,1 \%)$ vs $72(88,9 \%), \mathrm{P}=0.026)$. Dispersi terhadap interval elektromekanikal baik intra maupun inter atrium tidak berbeda pada kedua kelompok.

Kesimpulan. Interval elektromekanikal pada lateral atrium kiri dengan menggunakan doppler jaringan dapat digunakan sebagai prediktor terhadap kejadian AF pasca BPAK
\end{abstract}

(J Kardiol Indones. 2012;33:81-91)

Kata Kunci: Fibrilasi atrium, pasca bedah pintas arteri koroner, interval elektromekanikal, doppler jaringan, dispersi interval elektromekanikal.

\footnotetext{
Alamat Korespondensi

dr. Ignatius Yansen. Divisi Aritmia, Departemen Kardiologi dan Kedokteran Vaskular, FKUI dan Pusat Jantung Nasional Harapan Kita. Jln S

Parman Kav 87 Jakarta I | 420. E-mail: ignatius.jansen@gmail.com
} 
$\mathrm{F}$ ibrilasi atrium (AF) adalah kelainan aritmia yang paling banyak ditemui pasca operasi bedah pintas arteri koroner (BPAK), dengan insidensi yang sangat bervariasi dari beberapa studi yang pernah dilakukan. ${ }^{1}$ Fibrilasi atrium pasca BPAK menjadi sangat penting karena AF yang terjadi pasca bedah pintas koroner (BPAK) mempunyai prognosis jangka pendek dan jangka panjang yang kurang baik. Pasien yang menjalani operasi BPAK dan operasi katup memiliki tingkat insidensi AF pasca operasi yang lebih tinggi dibandingkan dengan operasi BPAK saja. Puncak insidensi dari AF terjadi pada hari ke 2 sampai hari ke 4 setelah operasi, dengan $<10 \%$ terjadi pada hari pertama. ${ }^{2}$

Fibrilasi atrium pasca BPAK dapat pulih dengan sendirinya. Walaupun tanpa komplikasi, aritmia ini membutuhkan terapi medikamentosa dan memperpanjang lama rawat di rumah sakit serta terkait dengan tambahan biaya perawatan. ${ }^{3} \mathrm{AF}$ pasca BPAK diketahui mempunyai potensi untuk terjadinya tromboembolisme sistemik, gangguan hemodinamik dan bahkan kejadian stroke, karena itu disarankan penggunaan amiodarone sebagai terapi profilaksis atau penggunaan pacu jantung atrium untuk menurunkan insidensi AF pasca BPAK. Pemberian terapi amiodarone intravena pada semua pasien yang menjalani operasi BPAK tidak efisien selain itu pemberian terapi ini terkait dengan efek samping yang tidak diinginkan. ${ }^{4}$ Dengan demikian diperlukan adanya penilaian faktor risiko dan juga prediktor terhadap kejadian AF pada pasien yang menjalani BPAK.

Angka kejadian AF pasca BPAK sangat bervariasi dari penelitian ke penelitian, hal ini tergantung dari demografi pasien, teknik pengambilan rekaman EKG, dan kriteria diagnosis nampaknya juga ikut menentukan serta jenis tindakan bedah pintas koroner (off pump atau on pump). Beberapa penelitian telah menggunakan beberapa parameter baik berdasarkan EKG mapun parameter echokardiografi (seperti durasi gelombang $\mathrm{P}$ dan volume dari atium kiri) untuk memprediksi kejadian AF pasca BPAK. Penelitianpenelitian ini memiliki beberapa kelemahan. ${ }^{1}$

$\mathrm{Omi}^{5}$ dan kawan-kawan telah menunjukkan bahwa interval elekromekanikal atrium yang memanjang dengan menggunakan dopper jaringan dapat memprediksi adanya gangguan konduksi di atrium pada AF yang paroksismal. Mereka menemukan bahwa waktu antara awal gelombang $\mathrm{P}$ pada EKG sampai awal dari gelombang A pada dopper jaringan memanjang pada $\mathrm{AF}$ yang paroksismal.

\section{Metodologi Penelitian}

Penelitian ini merupakan penelitian case control yang dilakukan di Departemen Kardiologi dan Kedokteran Vaskular FKUI / Pusat Jantung Nasional Harapan Kita, Jakarta pada periode Mei - September 2012. Populasi penelitian adalah semua pasien dengan penyakit jantung koroner yang menjalani operasi BPAK elektif. Subyek dieksklusi bila dilakukan operasi lain sepetri operasi katup dan kongenital bersamaan dengan BPAK, AF pre-operatif, operasi BPAK darurat, kualitas echokardiografi dan EKG yang tidak baik serta tidak mendapatkan persetujuan dari pasien.

\section{Cara kerja}

Sampel diambil secara konsekutif dari antara pasien-pasien yang akan menjalani operasi BPAK elektif di Pusat Jantung Nasional Harapan kita yang memenuhi kriteria inklusi dan tidak termasuk dalam kriteria eksklusi, serta setuju untuk mengikuti penelitian. Dilakukan pemeriksaan echokardiografi oleh sonografer ahli dengan menggunakan probe dari alat echokardiografi vivid 7 GE Medical System sehari sebelum operasi. Dilakukan pengukuran interval elektromekanikal secara echokardiografi dengan menggunakan doppler jaringan pada pandangan 4 chamber di apeks jantung dengan sampel diletakkan di lateral atrium kanan, septal dan lateral atrium kiri tepat di bawah anulus atrioventrikular. Interval elektromekanikal diukur dengan mengukur waktu antara awal gelombang P pada EKG sampai awal dari gelombang A pada dopper jaringan pada lateral atrium kanan, septal dan lateral atrium kiri. Dilakukan pengamatan terhadap kejadian AF pasca BPAK selama perawatan di rumah sakit. Dilakukan pengelompokkan antara grup dengan AF pasca BPAK dan yang tidak. Dilakukan analisa statistik untuk menilai faktor-faktor yang berhubungan dengan terjadinya AF pasca BPAK. Menilai interval elektromekanikal dan dispersi interval inter serta intra atrial sebagai prediktor terhadap kejadian AF pasca BPAK.

\section{Definisi operasional}

1. Data echo pre operasi didefinisikan sebagai pengambilan data echo sehari sebelum pasien menjadi operasi BPAK.

2. Dimensi ventrikel kiri dinilai dengan mengukur dimensi sistolik akhir dan dimensi diastolik akhir 
pada pandangan parasternal long axis.

3. Dimensi atrium kiri dinilai dengan melakukan pengukuran diameter atrium kiri dengan echocardiografi saat pandangan parasternal long aksis dan 4 chamber.

4. Indeks volume atrium kiri adalah rata-rata volume atrium kiri yang diukur dengan pandangan 4 chamber dan 2 chamber terhadap luas permukaan tubuh.

5. Hipertrofi ventrikel kiri adalah penebalan otot ventrkel kiri.

6. Disinkroni intraatrial kanan perbedaan interval elektromekanikal antara lateral atrium kanan dan septal.

7. Disinkroni intraatrial kiri perbedaan interval elektromekanikal antara lateral atrium kiri dan septal.

8. Disinkroni interatrial perbedaan interval elektromekanikal antara lateral atrium kiri dan atrium kanan.

9. Durasi gelombang $\mathbf{P}$ dinilai dengan mengukur durasi gelombang P pada lead II di EKG permukaan.

10. Fibrilasi atrium pasca BPAK didefinisikan sebagai kejadian AF selama perawatan rumah sakit pasca BPAK dengan durasi minimal 30 detik.

11. Fraksi ejeksi dinilai dengan formula Teichholz's

12. Interval elektromekanikal dinilai pada pandangan 4 chamber di apeks dengan mengukur jarak antara awal gelombang $P$ sampai awal gelombang A' pada doppler jaringan di lateral atrium kiri, atrium kanan dan septal tepat di bawah anulus atrioventrikular.

\section{Endpoint penelitian}

Endpoint primer dari penelitian ini adalah timbulnya AF awitan baru dalam rumah sakit yang berlangsung dengan durasi 30 detik baik itu simptomatik atau secara hemodinamik tidak stabil maupun asimtomatik dan terdokumentasi. Monitoring dilakukan secara kontinyu selama di ICU dan intermediate ward. Rekaman EKG 12 sadapan dilakukan setiap pagi setiap hari atau diambil bila ada keluhan seperti berdebar atau terdapat perubahan EKG pada EKG monitoring kontinyu.

\section{Analisis Statistik}

Uji Saphiro Wilk untuk melihat normalitas distribusi data. Mean \pm SD atau median (minimal-maksimal) untuk data kontinu dan proporsi untuk data kategorik. Perbandingan dilakukan antara variabel kontinu dengan menggunakan $t$ test atau Mann-Whitney bila sebaran data tidak normal dan antara variabel kategorikal dengan menggunakan chi-square. Regresi logistik untuk menilai prediktor. Batas kemaknaan $\mathrm{p}<0.05$. Analisa statistik menggunakan SPSS versi 15.0.

\section{Hasil Penelitian}

Selama Mei 2012 sampai dengan September 2012, terdapat 245 pasien yang menjalani BPAK secara elektif di Pusat Jantung Nasional Harapan Kita Jakarta. Dari sejumlah 245 pasien tersebut hanya terdapat 108 pasien yang diikutsertakan dalam penelitian ini yang telah memenuhi kriteria inklusi dan eksklusi penelitian.

Dari keseluruhan subyek yang dianalisis sebanyak 108 pasien sebagian besar (97 pasien/ 89,8\%) berjenis kelamin laki-laki. Terdapat 27 pasien (25\%) yang mengalami kejadian AF pasca BPAK dan 81 pasien (75\%) tidak mengalami kejadian AF pasca BPAK. Pasien yang mengalami AF pasca BPAK mempunyai kecenderungan umur yang lebih tua dengan rerata usia 62,4 tahun dibandingkan dengan pasien yang tidak mengalami AF dengan rerata usia 57,2 tahun. Selain dari usia pasien tidak ada perbedaan gambaran demografi pasien antara yang mangalami AF dan pasien yang tidak mengalami AF baik dari jenis kelamin, faktor-faktor risiko penyakit jantung koroner seperti diabetes, hipertensi, merokok dan dislipidemia

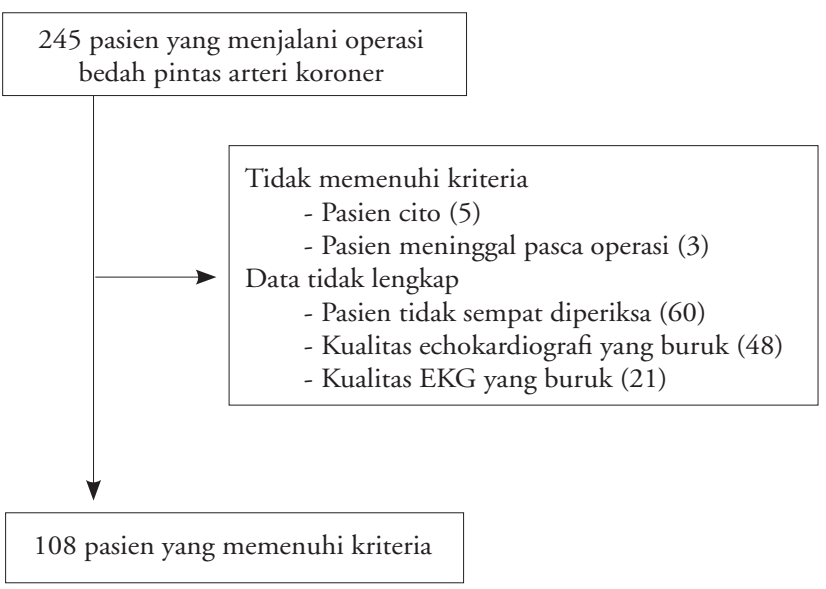

Gambar 1. Pemilihan pasien yang dimasukkan dalam analisa penelitian. 
serta obat-obatan yang diterima pasien sebelum dan setelah operasi. Terdapat kecenderungan bahwa pasien yang mengalami AF menerima obat penyekat reseptor beta yang lebih sedikit dibanding dengan yang tidak mengalami AF walaupun secara statistik tidak bermakna secara statistik. Tabel demografi pasien dapat dilihat dalam tabel 1.

Data-data intra operatif ditunjukkan pada tabel 2. Pada tabel ini diperlihatkan bahwa sebagian besar pasien $(88,8 \%)$ manjalani operasi secara on pump dan hanya sebagian kecil $(11,2 \%)$ yang menjalani operasi secara offpump walaupun tidak menunjukkan adanya perbedaan yang bermakna antara pasien yang mengalami $\mathrm{AF}$ dan yang tidak mengalami $\mathrm{AF}$ pasca
BPAK. Dari data ini juga meunjukkan bahwa tidak ada perbedaan yang bermakna waktu klem silang aorta, waktu CPB (Cardio Pulmonary Bypass) dan juga jumlah graft antara pasien yang mengalami AF yang tidak mengalami AF pasca BPAK.

Pemeriksaan echokardiografi dilakukan sehari sebelum operasi pada saat pasien masuk ke rumah sakit untuk melakukan persiapan operasi. Tabel 3 menunjukkan data echokardiografi dari pasien-pasien ini. Dari data ini menunjukkan bahwa pasien-pasien yang mengalami AF pasca BPAK mempunyai indeks volume atrium kiri yang lebih besar $(37,31 \pm 9,50$ $\mathrm{ml}$ ) dibanding pasien yang tidak mengalami AF $(30,28 \pm 8,19 \mathrm{ml})$ demikian juga dimensi atrium kiri

Tabel 1.Tabel demografi pasien

\begin{tabular}{lccc}
\hline Gambaran Klinis & $\mathrm{AF}(\mathrm{n}=27)$ & Tanpa AF $(\mathrm{n}=81)$ & Nilai P \\
\hline Usia (tahun) & $62,41 \pm 5,77$ & $57,28 \pm 6,59$ & $0,001^{*}$ \\
Jenis Kelamin & & & \\
$\quad$ Laki-laki & $25(92,6)$ & $72(88,9)$ & $0,727 \#$ \\
$\quad$ Perempuan & $2(7,4)$ & $9(11,1)$ & \\
Faktor risiko & & & \\
$\quad$ Diabetes mellitus & $12(44,4)$ & $36(44,4)$ & $1,000^{\prime \prime}$ \\
Hipertensi & $21(77,8)$ & $60(74,1)$ & $0,700^{\prime \prime}$ \\
Merokok & $9(33,3)$ & $38(46,9)$ & $0,218^{\prime}$ \\
Dislipidemia & $20(74,1)$ & $60(74,1)$ & $1,000^{\prime}$ \\
Medikamentosa & & & \\
Sebelum operasi & & & \\
Penyekat reseptor beta & $19(70,4)$ & $62(76,5)$ & $0,521 ”$ \\
Statin & $23(85,2)$ & $65(80,2)$ & $0,567 ”$ \\
Penyekat reseptor angiotensin & $16(59,3)$ & $45(55,6)$ & $0,737 ”$ \\
Diuretik & $4(14,8)$ & $6(7,4)$ & $0,264 \#$ \\
Digoksin & $1(3,7)$ & $0(0)$ & $0,250 \#$ \\
Setelah Operasi & & & \\
$\quad$ Penyekat reseptor beta & $20(74,1)$ & $72(88,9)$ & $0,113 \#$ \\
Statin & $26(96,3)$ & $79(97,5)$ & $1,000 \#$
\end{tabular}

Keterangan: "Uji Chi Square, \#Uji Fisher, ${ }^{*} U j i \mathrm{~T}$ tidak berpasangan

Tabel 2.Tabel data operasi

\begin{tabular}{lccc}
\hline Tindakan Operasi & $\mathrm{AF}(\mathrm{n}=27)$ & Tanpa AF $(\mathrm{n}=81)$ & Nilai P \\
\hline Jenis operasi & & & \\
On-pump & $5(18,5)$ & $74(91,4)$ & $0,157^{\prime}$ \\
Off-pump & $5(18,5)$ & $7(8,6)$ & \\
Waktu klem silang aorta (menit) & $65,5(35-193)$ & $63,5(35-197)$ & $0,865^{* *}$ \\
Waktu CPB (menit) & $103,5(49-228)$ & $103,5(49-255)$ & $0,972^{* *}$ \\
Jumlah graf & $3,5(3-5)$ & $4(2-5)$ & $0,728^{* *}$ \\
\hline
\end{tabular}

Keterangan: "Uji Chi Square, ${ }^{* *}$ uji Mann Whitney 
yang lebih besar pada pandangan parasternal long axis (37 mm vs $35 \mathrm{~mm}$ ). Tidak terdapat perbedaan yang bermakna pada fraksi ejeksi, dimensi diastolik dan sistolik akhir serta dimensi atrium kiri pada pandangan 4 chamber. Tabel 5.3 juga menunjukkan tidak ada perbedaan fungsi diastolik ventrikel kiri baik nilai E/A, E/e' maupun waktu deselerasi antara pasien yang mengalami AF dan yang tidak mengalami AF pasca BPAK.

Terdapat perbedaan panjang interval elektromekanikal yang bermakna diantara kedua grup baik interval elektromekanikal pada sisi lateral atrium kanan $(38,69 \pm 14,42 \mathrm{~ms}$ vs $32,50 \pm 11,89 \mathrm{~ms})$, septal $(52,03 \pm 11,41 \mathrm{~ms}$ vs $44,25 \pm 12,75 \mathrm{~ms})$ maupun pada sisi lateral atrium kiri $(81,12 \pm 9,84 \mathrm{~ms}$ vs $64,43 \pm 13,53$ $\mathrm{ms})$.

Di antara kedua grup juga terdapat perbedaan dispersi interval elektromekanikal yang bermakna intra atrial kiri $(29,09 \pm 12,53 \mathrm{~ms}$ vs $20,18 \pm 10,75 \mathrm{~ms})$ dan inter atrial $(42,42 \pm 15,14 \mathrm{~ms}$ vs $32,35 \pm 11,50 \mathrm{~ms})$ sedangkan tidak terdapat perbedaan yang bermakna dispersi interval elektromekanikal intra atrial kanan. Dari pemeriksaan EKG didapatkan perbedaan yang bermakana durasi gelombang $\mathrm{P}$ pada kedua grup $(95,28 \pm 15,10 \mathrm{~ms}$ vs $81,19 \pm 15,33 \mathrm{~ms})$.

Dari keseluruhan univariat di atas, variable yang bermakna dengan $\mathrm{p}<0.25$ dilakukan analisa multivariat dan didapatkan bahwa prediktor independen terhadap kejadian AF pasca BPAK ada 3 yaitu interval elektromekanikal di lateral atrium kiri, indeks volume atrium kiri dan obat penyekat reseptor beta yang diberikan pasca operasi (tabel 4.). Interval elektromekanikal yang panjang meningkatkan risiko terhadap AF pasca BPAK dengan OR 1.145 untuk setiap milisekon (IK 95\% 1.074- 1.219, p=0.00), LAVI meningkatkan risiko terhadap AF pasca BPAK dengan OR 1.069 untuk setiap $\mathrm{ml} / \mathrm{m} 2$ (IK 95\% 1.004-1.139, $\mathrm{p}=0.037)$ sedangkan obat penyekat reseptor beta yang diberikan setelah operasi memberikan proteksi terhadap kejadian AF pasca BPAK dengan OR 0.184 (IK 95\% 0.042-0.813, p=0.026)

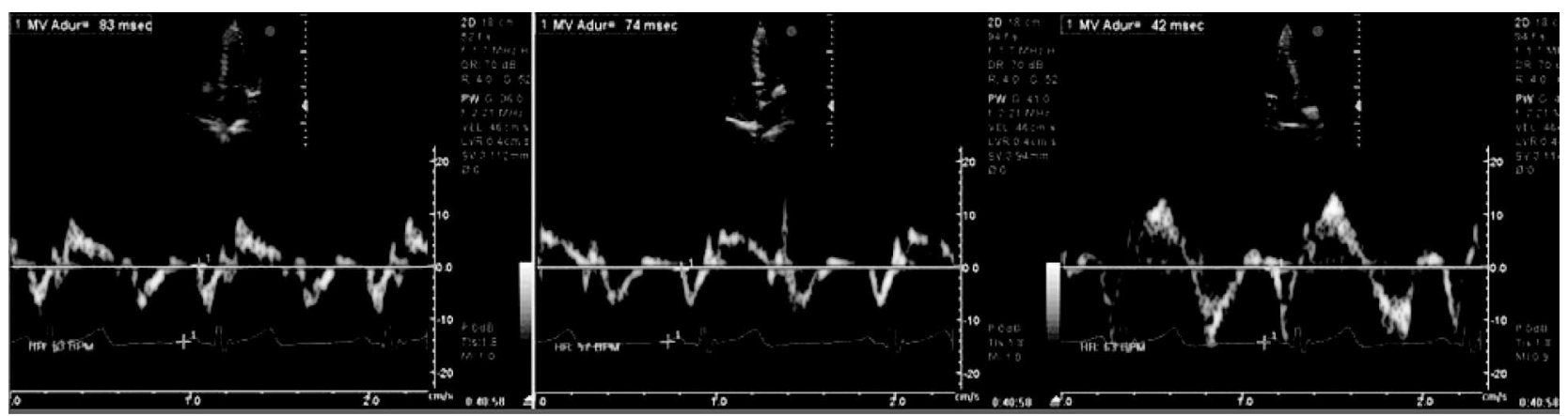

Gambar 2. Gambaran doppler jaringan pada lateral atrium kiri, septal dan lateral atrium kanan. ${ }^{21}$

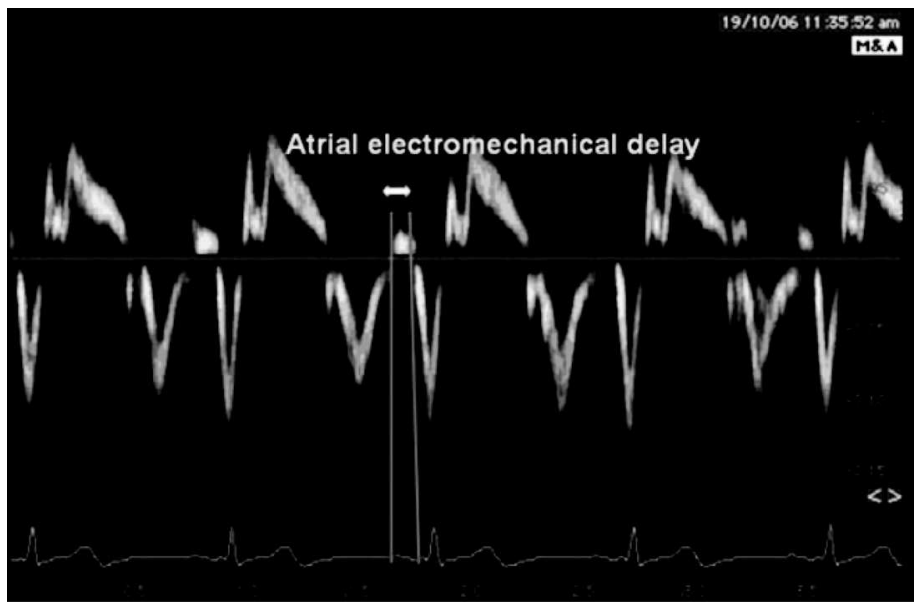

Gambar 3. Cara mengukur interval elektromekanikal. ${ }^{21}$ 
Yansen I dkk: Interval elektromekanikal atrium sebagai prediktor kejadian fibrilasi atrium pasca operasi

Tabel 3. Data echokardiografi

\begin{tabular}{|c|c|c|c|}
\hline Parameter echocardiografi & $\mathrm{AF}(\mathrm{n}=27)$ & Tanpa AF $(\mathrm{n}=81)$ & Nilai $\mathrm{P}$ \\
\hline Fraksi ejeksi (\%) & $67,5(25-82)$ & $67(25-83$ & $0,402^{* *}$ \\
\hline \multicolumn{4}{|l|}{ Dimensi ventrikel kiri (mm) } \\
\hline EDD & $49,91 \pm 8,83$ & $48,78 \pm 5,63$ & $0,216^{*}$ \\
\hline ESD & $32,5(17-60)$ & $30(19-50$ & $0,313^{* *}$ \\
\hline Indeks volume atrial kiri & $37,31 \pm 9,50$ & $30,28 \pm 8,19$ & $0,001^{*}$ \\
\hline \multicolumn{4}{|l|}{ Dimensi atrium kiri (mm) } \\
\hline Parasternal long axis & $37(30-49)$ & $35(25-56)$ & $0,018^{* *}$ \\
\hline 4 chamber & $48,5(36-72)$ & $48(37-63)$ & $0,326^{* *}$ \\
\hline \multicolumn{4}{|l|}{ Fungsi diastolik ventrikel kiri } \\
\hline $\mathrm{E} / \mathrm{A} \quad<1$ & $23(85,2)$ & $59(72,8)$ & 0,383 \\
\hline$>1$ & $3(11,1)$ & $19(23,5)$ & \\
\hline$>2$ & $1(3,7)$ & $3(3,7)$ & \\
\hline $\mathrm{E} / \mathrm{e}^{\prime}$ & $11,85(6,62-32,64)$ & $10,66(6,08-27,01)$ & $0,129^{* *}$ \\
\hline DT & $230,64 \pm 68,75$ & $227,47 \pm 47,31$ & $0,725^{*}$ \\
\hline \multicolumn{4}{|l|}{ Interval elekromekanikal (ms) } \\
\hline Sisi lateral atrium kanan & $38,69 \pm 14,42$ & $32,50 \pm 11,89$ & $0,008^{*}$ \\
\hline Septal & $52,03 \pm 11,41$ & $44,25 \pm 12,75$ & $0,000^{*}$ \\
\hline Sisi lateral atrium kiri & $81,12 \pm 68,75$ & $64,43 \pm 13,53$ & $0,000^{*}$ \\
\hline \multicolumn{4}{|c|}{ Perbedaan Interval elekromekanikal (ms) } \\
\hline Intra atrial kanan & $17,4(0,10-28,10)$ & $13,65(0,10-51,9)$ & $0,252^{* *}$ \\
\hline Intra atrial kiri & $29,09 \pm 12,53$ & $20,18 \pm 10,75$ & $0,002^{*}$ \\
\hline Intra atrial & $42,42 \pm 15,14$ & $32,35 \pm 11,50$ & $0,000^{*}$ \\
\hline Durasi gelombang $\mathrm{p}(\mathrm{ms})$ & $95,28 \pm 15,10$ & $81,19 \pm 15,33$ & $0,000^{*}$ \\
\hline
\end{tabular}

Keterangan: ${ }^{*} \mathrm{Uji} \mathrm{T}$ tidak berpasangan, ${ }^{* *}$ uji Mann Whitney

Tabel 4.Tabel analisis multivariat faktor-faktor prediktor terhadap kejadian AF pasca BPAK.

\begin{tabular}{lccccc}
\hline & & & & \multicolumn{2}{c}{ 95.0\% C.I.for Adjusted OR } \\
\cline { 5 - 6 } & $\mathrm{B}$ & Sig. & Adjusted OR $(\operatorname{Exp}(\mathrm{B}))$ & Lower & Upper \\
\hline BB_post_OP.M & -1.694 & .026 & .184 & .042 & .813 \\
LAVI & .067 & .037 & 1.069 & 1.004 & 1.139 \\
Lat_LA & .135 & .000 & 1.145 & 1.074 & 1.219 \\
Constant & -11.862 & .000 & .000 & & \\
\hline
\end{tabular}

Tabel 5. Tabel Area under the curve dari ketiga variable

Area Under the Curve

\begin{tabular}{|c|c|c|c|}
\hline \multirow[b]{2}{*}{ Test Result variable (s) } & \\
\hline & Area under the curve & Asymptotic Sig. (b) & Asymptotic $95 \%$ Confidence Interval \\
\hline 3 VAR (BB, LAVI, LA) & .891 & .000 & $\begin{array}{ll}.831 & .951\end{array}$ \\
\hline 2 VAR (LAVI, LA) & .878 & .000 & .942 \\
\hline 1 VAR (LA) & .858 & .000 & .929 \\
\hline
\end{tabular}

Tabel 6. Perbandingan hasil penilaian test-retest reliability dan inter rater reliability untuk pengukuran interval elektromekanikal

\begin{tabular}{|c|c|c|c|c|}
\hline & Median & Minimum & Maximum & $\mathrm{p}$ \\
\hline Int_kiri_A & 71.20 & 21.80 & 100.25 & referensi \\
\hline Int_kiri_B & 69.50 & 22.00 & 96.40 & 0,459 \\
\hline Int_kiri C & 71.15 & 23.60 & 92.30 & 0,571 \\
\hline Int_septal_A & 48.34 & 11.20 & 70.20 & Referensi \\
\hline Int_septal_B & 47.70 & 12.10 & 72.10 & 0,130 \\
\hline Int_septal C & 45.65 & 9.00 & 74.60 & 0,066 \\
\hline int_kanan_A & 37.50 & 5.00 & 63.60 & Referensi \\
\hline Int_kanan_B & 35.30 & 5.00 & 60.60 & 0,118 \\
\hline Int_kanan C & 35.65 & 5.00 & 57.00 & 0,12 \\
\hline
\end{tabular}

Keterangan: perbandingan A dan B: test-retest reliability, Perbandingan A dan C: inter rater reliability 
Berdasarkan hasil analisis multivariat didapatkan rumus pesrsamaan prediksi AF berdasarkan hasil regresi logistik
Dari seluruh pasien yang mengalami AF pasca BPAK, irama sinus dapat dikembalikan dengan pemberian anti aritmia amiodarone sesuai dengan

$$
\text { Kemungkinan AF }(\%)=\frac{1}{e^{(-11,86-1.9(B B)+0,13(\text { lat LA })+0,67(L A V I)}}
$$

\section{Kemungkinan AF (\%)}

Dengan kemungkinan AF bila didapatkan nilai lebih dari 50\%. Gambar 4 dan tabel 5 menggambarkan area under curve dari ketiga parameter terhadap kejadian AF pasca BPAK. Dari keterangan ini dapat dilihat kalau parameter interval elektromekanikal di lateral LA merupakan prediktor terkuat terhadap kejadian AF pasca BPAK dibandingkan dengan kedua parameter lainnya dengan AUC 85,8\%.

Dengan analisis variabilitas, derajat kesesuaian inter dan antar pengamat dari parameter interval elektromekanikal baik yang di lateral LA, septal maupun lateral RA terlihat cukup baik dan tidak ditemukan adanya perbedaan yang bermakna diantara ketiga rerata baik inter maupun intra pengamat. (tabel 6)

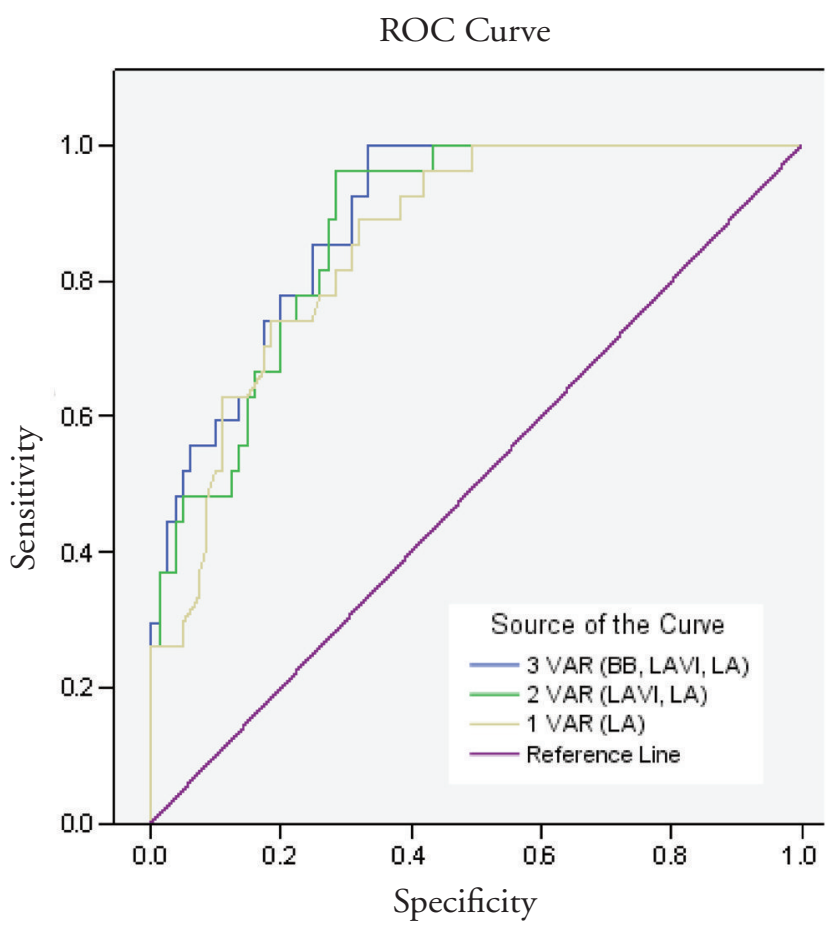

Gambar 4. Kurva ROC untuk ketiga variabel (Interval elektromekanikal di lateral LA, penyekat reseptor beta dan LAVI) prosedur yang berlaku di Pusat Jantung Nasional Harapan Kita.

\section{Diskusi}

Fibrilasi atrium adalah komplikasi aritmia yang paling sering terjadi setelah operasi BPAK. ${ }^{6}$ Meskipun kemajuan di bidang $\mathrm{CPB}$, kardioplegik dan tehnik bedah, insidensnya secara paradoks meningkat pada beberapa tahun terakhir seiring dengan meningkatnya usia pasien yang dibedah dan kemajuan pada teknologi monitoring EKG yang kontinyu. Kejadian AF pasca BPAK secara bermakna meningkatkan angka kematian dan juga angka kesakitan baik jangka pendek maupun jangka panjang. Keluhan yang biasa yang dialami pasien adalah sesak nafas, rasa tidak nyaman di dada, instabilitas hemodinamik dan kejadian tromboembolik. ${ }^{2}$,-9 Pada penelitian ini didapatkan angka insidens kejadian AF pasca BPAK sebanyak $25 \%$. Hal ini tidak jauh berbeda dari penelitian yang dilakukan oleh Hadis ${ }^{10}$ dan kawan-kawan yang menunjukkan angka kejadian AF pasca BPAK di PJNHK adalah sebesar 26,1\%.

Upaya untuk memprediksi kejadian AF menjadi begitu penting untuk mengurangi angka kesakitan dan kematian serta biaya dan lama rawat di rumah sakit. Anti aritmia seperti amiodarone yang diberikan secara intravena dan dilanjutkan dengan oral merupakan terapi yang efektif untuk mencegah timbulnya kejadian AF pasca BPAK tetapi pemberian amiodarone mempunyai efek samping yang sangat serius sehingga perlu diberikan secara selektif terutama pada pasien yang mempunyai faktor risiko tinggi timbulnya kejadian AF pasca BPAK. ${ }^{4}$ Dengan demikian, indentifikasi terhadap faktor risiko seorang pasien menjadi penting.

Beberapa parameter telah diteliti untuk memprediksi kejadian AF pasca BPAK. Parameter-parameter itu baik secara EKG maupun echokardiografi. Secara EKG peneliti menilai bahwa durasi gelombang $P$ dan adanya dispersi gelombang P baik dari EKG 12 sadapan atau 
menggunakan SAECG dapat memprediksi kejadian AF pasca BPAK. ${ }^{11-16}$ Interval elektromekanikal yang diperiksa dengan menggunakan doppler jaringan pada echokardiografi dapat dijadikan prediktor terhadap kejadian AF pasca BPAK. ${ }^{29}$ Pemeriksaan ehokardiografi adalah modalitas yang rutin dilakukan pada pasien yang akan menjalani operasi BPAK. Keunggulan dari doppler jaringan dibandingkan pemeriksaan echokardiografi yang lainnya adalah tidak dipengaruhi oleh denyut jantung, preload, afterload. 526,17 Pemeriksaan ini adalah pemeriksaan yang mudah, murah dan dapat ditambahkan pada pemeriksaan echokardiografi rutin yang dilakukan oleh pasien yang akan menjalani operasi BPAK.

Pada penelitian ini telah dilakukan pemeriksaan interval elektromekanikal dengan doppler jaringan pada pasien-pasien yang akan menjalani operasi BPAK. Interval elektromkanikal diperiksa pada sisi lateral atrium kiri, septal dan sisi lateral atrium kanan tepat dibawah annulus atrioventrikular. Panjang interval dan adanya dispersi terhadap panjang interval elektromekanikal diharapkan dapat menjadi prediktor terhadap kejadian AF pasca BPAK. Pasien diikuti selama perawatan di rumah sakit untuk mendeteksi timbulnya kejadian AF. Pemerikaan interval elektromekanikal menggambarkan adanya gangguan kondusi di atrium. Hal ini merupakan dasar timbulnya AF.

Dalam Penelitian ini secara univariat menunjukkan bahwa parameter yang bermakna antara pasien yang mengalami AF dan tidak adalah usia, indeks volume atrium kiri, dimensi atrium kiri pada pandangan parasternal long axis, panjang interval elektromekanikal pada lateral atrium kiri, septal dan lateral atrium kanan serta dispersi intra atrial kiri, dispersi interatrial, dan panjang gelombang P pada ECG. Faktor risiko yang paling konsisten terhadap kejadian AF pasca BPAK dari berbagai penelitian adalah faktor usia.

Setelah dilakukan analisis multivariate terdapat 3 parameter yang secara bermakna berbeda antara pasien yang mengalami AF dengan pasien yang tidak mengalami AF pasca BPAK. Ketiga parameter tersebut adalah interval elektromekanikal pada sisi lateral atrium kiri, indeks volume atrium kiri dan terapi penyekat reseptor beta pasca operasi. Interval elektromekanikal di lateral atrium kiri merupakan prediktor yang paling kuat terhadap kejadian AF pasca BPAK dengan area under curve mencapai $85,8 \%$. Pasien yang memiliki interval elektromekanikal yang panjang merupakan prediktor terhadap kejadian AF pasca BPAK. Interval elektromekanikal yang memanjang menggambarkan adanya gangguan konduksi di atrium dari nodus SA ke sisi terjauh dari atrium yaitu pada sisi lateral atrium kiri. Adanya perlambatan konduksi di atrium merupakan mekanisme terhadap kejadian $\mathrm{AF} .{ }^{18} \mathrm{Hal}$ ini sesuai dengan penelitian sebelumnya yang dilakukan oleh Roshanali. ${ }^{29}$ Dengan demikian pasien-pasien yang mempunyai interval elektromekanikal yang memanjang menunjukkan bahwa sudah terdapat substrat sebelum operasi yang mendasari timbulnya AF. ${ }^{19} \mathrm{Hal}$ ini yang mengambarkan mengapa terdapat kerentanan interindividu untuk terjadinya AF. Substrat ini menggambarkan adanya gangguan konduksi sebelum pasien menjalani operasi sehingga memudahkan untuk terjadinya gelombang re-enrty di atrium dan meningkatkan kejadian AF pasca BPAK. Hal ini terkait dengan adanya remodeling pada atrium yang ditandai dengan berkurangnya serat-serat miokardial dan meningkatnya fibrosis. ${ }^{20}$ Fibrosis ini menyebabkan heterogenitas struktur dan properti elektrofisiologi miokardium atrium sehingga akan merubah masa refrakter atrium dan kecepatan konduksi yang akan menyebabkan peningkatan gelombang re-entry. Teori fibrosis ini didukung oleh penemuan dari Goette ${ }^{21}$ dan kawan-kawan yang menganalisis specimen apendiks atrium kanan yang diambil sewaktu operasi bedah jantung. Ternyata mereka menemukan bahwa terdapat hubungan antara fibrosis antrium dengan terjadinya AF pasca bedah jantung.

Interval elektromekanikal pada septal dan sisi lateral atrium kanan pada penelitian ini tidak menunjukkan kemaknaan setelah dilakukan analisis multivariat. Parameter yang bermakna lainnya adalah index volume atrium kiri. Terdapat perbedaan indeks volume atrium kiri yang bermakna antara pasien yang mengalami $\mathrm{AF}$ dan pasien yang tidak mengalami $\mathrm{AF}$ pasca BPAK. Indeks volume atrium kiri yang semakin besar merupakan prediktor terhadap kejadian AF pasca BPAK. Indeks volume atrium kiri yang semakin besar menunjukkan adanya dilatasi atrium kiri sehingga terjadi perlambatan konduksi di atrium dan dimensi yang semakin besar dapat menampung semakin banyak gelombang re-entry sehingga memudahkan terjadinya kejadian $\mathrm{AF}^{22,23} \mathrm{Hal}$ ini juga sesuai dengan penelitian yang telah dilakukan sebelumnya.

Terapi penyekat reseptor beta pasca operasi juga secara bermakna menunjukkan perbedaan diantara kedua grup dan merupakan prediktor yang terhadap kejadian AF pasca BPAK. Hal ini sesuai dengan mekanisme AF. ${ }^{19,}{ }^{24}$ Pasien yang mengalami AF pasca BPAK juga didapatkan peningkatan kadar nore- 
pinefrin pasca operasi. Aktivitas simpatis juga dapat memperpendek periode refrakter secara heterogen yang mempermudah terjadinya aritmia. Proses ini juga menyebabkan produksi katekolamin yang meningkat, adanya ketidakseimbangan otonom pasca operasi. Dengan pemberian obat penyekat reseptor beta kejadian AF pasca CABG dapat diturunkan..$^{25,26}$

\section{Keterbatasan Penelitian}

Insidensi dari AF pasca BPAK pada penelitian ini mungkin underestimate karena adanya perbedaan metode deteksi di ICU, ruang intermediate dan ruang perawatan dimana deteksi hanya dengan pemeriksaan ECG rutin perhari atau berdasarkan keluhan pasien setelah pasien berada di ruang perawatan. Pemeriksaan menggunakan holter memungkinkan untuk monitoring yang lebih baik.

\section{Daftar Pustaka}

1. Hakala T, Hedman A. Predicting the risk of atrial fibrillation after coronary artery bypass surgery. Scand Cardiovasc J. 2003; 37(6): 309-15.

2. Aranki SF, Shaw DP, Adams DH, Rizzo RJ, Couper GS, VanderVliet M, et al. Predictors of atrial fibrillation after coronary artery surgery. Current trends and impact on hospital resources. Circulation. 1996; 94(3): 390-7.

3. Creswell LL, Damiano RJ, Jr. Postoperative atrial fibrillation: an old problem crying for new solutions. J Thorac Cardiovasc Surg. 2001; 121(4): 638-41.

4. Mahoney EM, Thompson TD, Veledar E, Williams J, Weintraub WS. Cost-effectiveness of targeting patients undergoing cardiac surgery for therapy with intravenous amiodarone to prevent atrial fibrillation. J Am Coll Cardiol. 2002; 40(4): 737-45.

5. Omi W, Nagai H, Takamura M, Okura S, Okajima M, Furusho $\mathrm{H}$, et al. Doppler tissue analysis of atrial electromechanical coupling in paroxysmal atrial fibrillation. J Am Soc Echocardiogr. 2005; 18(1): 39-44.

6. Creswell LL, Schuessler RB, Rosenbloom M, Cox JL. Hazards of postoperative atrial arrhythmias. Ann Thorac Surg. 1993; 56(3): 539-49.

7. Villareal RP, Hariharan R, Liu BC, Kar B, Lee VV, Elayda M, et al. Postoperative atrial fibrillation and mortality after coronary artery bypass surgery. J Am Coll Cardiol. 2004; 43(5): 742-8.

8. Almassi GH, Schowalter T, Nicolosi AC, Aggarwal A, Moritz TE, Henderson WG, et al. Atrial fibrillation after cardiac surgery: a major morbid event? Ann Surg. 1997; 226(4): 501-11; discussion 11-3.

9. Mathew JP, Parks R, Savino JS, Friedman AS, Koch C, Mangano DT, et al. Atrial fibrillation following coronary artery bypass graft surgery: predictors, outcomes, and resource utilization. MultiCenter Study of Perioperative Ischemia Research Group. JAMA. 1996; 276(4): 300-6.

10. Hadis H, Yuniadi Y, Idham I. Incidence and risk factors of atrial fibrillation after coronary bypass graft surgery. J Kardiol Indones. 2010; 31: 16-25.

11. Ariyarajah V, Mercado K, Apiyasawat S, Puri P, Spodick DH. Correlation of left atrial size with $\mathrm{p}$-wave duration in interatrial block. Chest. 2005; 128(4): 2615-8.

12. Dilaveris PE, Gialafos EJ, Sideris SK, Theopistou AM, Andrikopoulos GK, Kyriakidis M, et al. Simple electrocardiographic markers for the prediction of paroxysmal idiopathic atrial fibrillation. Am Heart J. 1998; 135(5 Pt 1): 733-8.

13. Dilaveris PES, C.I. P wave dispersion: A valuable non-invasive marker of vulnerability to atrial arrhythmias. Hospital chronicles. 2006; 1(3): 130-7.

14. Weber UK, Osswald S, Huber M, Buser P, Skarvan K, Stulz P, et al. Selective versus non-selective antiarrhythmic approach for prevention of atrial fibrillation after coronary surgery: is there a need for pre-operative risk stratification? A prospective placebo-controlled study using low-dose sotalol. Eur Heart J. 1998; 19(5): 794-800.

15. Chandy J, Nakai T, Lee RJ, Bellows WH, Dzankic S, Leung JM. Increases in P-wave dispersion predict postoperative atrial fibrillation after coronary artery bypass graft surgery. Anesth Analg. 2004; 98(2): 303-10, table of contents.

16. Yamada T, Fukunami M, Shimonagata T, Kumagai K, Sanada $\mathrm{S}$, Ogita $\mathrm{H}$, et al. Dispersion of signal-averaged $\mathrm{P}$ wave duration on precordial body surface in patients with paroxysmal atrial fibrillation. Eur Heart J. 1999; 20(3): 211-20.

17. Sakabe K, Fukuda N, Fukuda Y, MorishitaS, Shinohara H, Tamura Y. Interatrial dyssynchrony on tissue Doppler imaging predicts progression to chronic atrial fibrillation in patients with non-valvular paroxysmal atrial fibrillation. Heart. 2009; 95(12): 988-93.

18. Platonov PG. Interatrial conduction in the mechanisms of atrial fibrillation: from anatomy to cardiac signals and new treatment modalities. Europace. 2007; 9 Suppl 6: vi10-6.

19. Maesen B, Nijs J, Maessen J, Allessie M, Schotten U. Postoperative atrial fibrillation: a maze of mechanisms. Europace. 2012; 14(2): 159-74.

20. Spach MS, Dolber PC. Relating extracellular potentials and their derivatives to anisotropic propagation at a microscopic level in human cardiac muscle. Evidence for electrical uncoupling of side-to-side fiber connections with increasing age. Circ Res. 1986; 58(3): 356-71.

21. Goette A, Juenemann G, Peters B, Klein HU, Roessner A, Huth $\mathrm{C}$, et al. Determinants and consequences of atrial fibrosis in 
Yansen I dkk: Interval elektromekanikal atrium sebagai prediktor kejadian fibrilasi atrium pasca operasi

patients undergoing open heart surgery. Cardiovasc Res. 2002; 54(2): 390-6.

22. Nakai T, Lee RJ, Schiller NB, Bellows WH, Dzankic S, Reeves $\mathrm{J}, 3 \mathrm{rd}$, et al. The relative importance of left atrial function versus dimension in predicting atrial fibrillation after coronary artery bypass graft surgery. Am Heart J. 2002; 143(1): 181-6.

23. Osranek M, Fatema K, Qaddoura F, Al-Saileek A, Barnes ME, Bailey KR, et al. Left atrial volume predicts the risk of atrial fibrillation after cardiac surgery: a prospective study. J Am Coll Cardiol. 2006; 48(4): 779-86.

24. Kalman JM, Munawar M, Howes LG, Louis WJ, Buxton BF,
Gutteridge G, et al. Atrial fibrillation after coronary artery bypass grafting is associated with sympathetic activation. Ann Thorac Surg. 1995; 60(6): 1709-15.

25. Burgess DC, Kilborn MJ, Keech AC. Interventions for prevention of post-operative atrial fibrillation and its complications after cardiac surgery: a meta-analysis. Eur Heart J. 2006; 27(23): 2846-57.

26. Crystal E, Connolly SJ, Sleik K, Ginger TJ, Yusuf S. Interventions on prevention of postoperative atrial fibrillation in patients undergoing heart surgery: a meta-analysis. Circulation. 2002; 106(1): 75-80. 